\title{
RESPONSABILIDADE CIVIL DO ESTADO EM REPARAR OS DANOS MORAIS CAUSADOS AOS PRESOS EM SITUAÇÃO DEGRADANTE: ANÁLISE DO RE 580.252
}

\section{CIVIL LIABILITY OF THE STATE IN FIXING THE MORAL DAMAGES CAUSED TO PRISONERS IN A DEGRADING SITUATION: ANALYSIS} OF THE RE 580.252

\author{
JULIANO DEFUNE FLENICK
}

Advogado. Aluno do Mestrado em Direito Empresarial e Cidadania da UNICURITIBA.

\section{PRISCILA NASCIMENTO GIUBLIN GOMES DE SOUZA LUZ}

Advogada. Aluna do Mestrado em Direito Empresarial e Cidadania da UNICURITIBA.

\section{RESUMO}

A situação carcerária do Brasil há muito, encontra-se em situação desumana e degradante, o que fere direitos fundamentais dos presos. O Estado, que possuiu a custódia dos detentos, tem o dever de manter condições de vida digna aos mesmos. Questionado pelo Recurso Extraordinário 580.252, o Supremo Tribunal Federal analisou a responsabilidade civil do Estado por danos morais causados aos presos em situação ilegítima e sub-humana. Julgando-o procedente, foi conferida repercussão geral à demanda. Incontroversos os fatos, o debate ficou restrito à forma de indenização por parte do Estado, fixado em restituição pecuniária fixa ao preso, em consonância com a "Agenda do Sistema Prisional" conduzida pelo Supremo Tribunal Federal, numa linha mais ativa, em que o Judiciário vem determinando aos Estados, ou seja, ao Poder Executivo, diversas obrigações de fazer em prol do sistema prisional brasileiro. 


\title{
Personalidade Acadêmica Homenageada:
}

Carlos Aurélio Mota de Souza (Universidade Ibirapuera - UNIB)

PALAVRAS-CHAVE: Sistema Prisional; Danos Morais; Presos; Responsabilidade Civil; Estado.

\begin{abstract}
Brazil's prison situation has long been inhuman and degrading, which is a violation of prisoners' fundamental rights. The State, which has the custody of the detainees, has the duty to maintain a dignified life. Asked about Extraordinary Appeal 580.252, the Federal Supreme Court analyzed the civil liability of the State for moral damages caused to illegitimate and subhuman prisoners. If it was upheld, there was a general repercussion on the claim. Uncontroversial the facts, the debate was restricted to the form of indemnity by the State, fixed in fixed pecuniary restitution to the prisoner, in line with the "Agenda of the Prison System" conducted by the Federal Supreme Court, in a more active line, in which the Judiciary has been determining to the States, that is, to the Executive Branch, several obligations to do in favor of the Brazilian prison system.
\end{abstract}

KEYWORDS: Prison System; Moral Damages; Prisoners; Civil Liability; State.

\section{INTRODUÇÃO}

A situação carcerária do Brasil, há muito, encontra-se em situação desumana e degradante. Em que pesem os esforços dos Estados e da União para a sua manutenção do sistema prisional, os recursos destinados são insuficientes para a enorme demanda de presos, sequer existe vontade política para uma atuação proativa em prol dos detentos, estes marginalizados e excluídos da sociedade.

Os presos têm o direito fundamental à integridade física e moral, assegurado pelo artigo 5-XLIX da Constituição, e o Estado, ao assumir a custódia dos mesmos, recebe o dever de conferir condições dignas de vida aos mesmos. 
Personalidade Acadêmica Homenageada:

Carlos Aurélio Mota de Souza (Universidade Ibirapuera - UNIB)

Neste contexto, o Supremo Tribunal Federal foi questionado sobre a possibilidade de responsabilidade civil do Estado por danos morais causados aos presos, que se encontram em situação degradante, no Recurso Extraordinário 580.252.

Atendendo a sua função contra majoritária, a Corte Constitucional deu procedência ao pedido formulado, por maioria, acompanhando o voto do Relator Teori Zavaski, conferindo, inclusive, repercussão geral à demanda, para a responsabilização civil dos Estados diante do dano moral causado aos presos, colocados em situações desumanas.

O debate entre os Ministros do Supremo Tribunal Federal foi intenso, e de grande interesse jurídico pelas argumentações desenvolvidas. Destaca-se, o voto divergente proferido pelo Ministro Roberto Barroso, que restou vencido, mas que trouxe uma solução ímpar para a questão.

Diante dos fatos, danos e nexo causal incontroversos, o debate ficou restrito à forma de indenização por parte do Estado, a qual tangenciou uma linha mais ativista, do citado Ministro.

Ainda que o voto divergente, não tenha obtido a maioria, o presente artigo pretende examinar o Recurso Extraordinário 580.252, que como um todo, está em consonância com a "Agenda do Sistema Prisional" conduzida pelo Supremo Tribunal Federal, numa linha mais ativa, em que o Judiciário que vem determinando aos Estados - Poder Executivo - diversas obrigações de fazer em prol do sistema prisional.

\section{OS FATOS DO RE $\mathbf{5 8 0 . 2 5 2}$}

O saudoso Ministro Teori Zavascki, relator do caso, esclarece em seu relatório ${ }^{1}$, que o Recurso Extraordinário 580.252 trata de pedido de revisão de demanda movida por detento condenado à pena de 20 anos de reclusão, visando ao

${ }^{1}$ RE 580.252, p. 04. 


\title{
Personalidade Acadêmica Homenageada: \\ Carlos Aurélio Mota de Souza (Universidade Ibirapuera - UNIB)
}

pagamento de indenização por dano moral, causado pelas ilegítimas e sub-humanas condições a que está submetido no cumprimento de pena em estabelecimento prisional situado no Município de Corumbá, Mato Grosso do Sul.

Em primeiro grau, o pedido foi julgado improcedente. Em sede de apelação, o julgamento foi reformado, conforme a seguinte ementa:

\begin{abstract}
EMENTA - APELAÇÃO CÍVEL - AÇÃO DE INDENIZAÇÃO - DANO MORAL CARACTERIZADO - TEORIA DA RESERVA DO POSSIIVEL CONJUGADA COM O MÍNIMO EXISTENCIAL - PREQUESTIONAMENTO MATÉRIA SUFICIENTEMENTE DEBATIDA E DISCUTIDA PELO ÓRGÃO COLEGIADO - RECURSO PROVIDO. O Estado será responsabilizado a indenizar quando, por ato omissivo, tenha causado dano à particular, desde que comprovada a conduta culposa ou dolosa do ente federativo. Demonstrado que os problemas de superlotação e de falta de condições mínimas de saúde e higiene do estabelecimento penal (presídio) não foram sanados, após o decurso de um lapso temporal quando da formalização do laudo de vigilância sanitária, violando, por conseguinte, as disposições da Lei de Execução Penal, bem como a Convenção Interamericana de Direitos Humanos, está devidamente comprovada a conduta omissiva culposa do Estado (culpa administrativa). Não sendo assegurado o mínimo existencial, não há falar em aplicação da teoria da reserva do possível. Recurso provido. ${ }^{2}$
\end{abstract}

Destarte, foi fixado a título de indenização por danos morais, o valor de $R \$$ 2.000,00 (dois mil reais).

Opostos embargos infringentes, estes restaram acolhidos e a sentença de improcedência restaurada, com base no fundamento de que a omissão do Estado não é ilícita, pois este atua dentro da "reserva do possível, ou seja, dentro das disponibilidades orçamentárias da Administração Pública" e, também, porque o direito do autor não pode ser considerado absoluto diante dos limites do Estado.

Em recurso extraordinário, a parte recorrente aponta ofensa aos artigos 5, incisos III, X, XLIX e artigo 37, §6 da Constituição da República, e ao artigo 5 do Pacto de São José da Costa Rica, asseverando, em suma, que:

[...] a submissão do recorrente e outros detentos na mesma penitenciária a tratamento desumano e degradante foi expressamente reconhecida pelo acórdão recorrido, o que lhe causa anormal sofrimento configurador de dano moral indenizável; (b) é dever do Estado atender minimamente as condições

2 Idem. 


\title{
Personalidade Acadêmica Homenageada: \\ Carlos Aurélio Mota de Souza (Universidade Ibirapuera - UNIB)
}

\begin{abstract}
carcerárias previstas em lei relativamente aos que estão sob sua custódia, inclusive no sentido de reeducá-los para o retorno à sociedade; (c) o próprio recorrido admite, publicamente, o caos do sistema prisional do Estado do Mato Grosso do Sul, tendo o Governador reeditado, por diversas vezes, o Decreto "E" n. 41, de 16/05/2005, no qual faz as considerações necessárias para decretar a "Situação de Emergência" dos Presídios em decorrência "do colapso do Sistema Penitenciário"; (d) o princípio da reserva do possível não pode ser abstratamente invocado, sob pena do Estado utilizar-se desse argumento para afastar sua responsabilidade em diversas áreas de sua atuação. $^{3}$
\end{abstract}

A Procuradoria-Geral da República e a União, na condição de amicus curiae, manifestaram-se pelo desprovimento do recurso.

Submetido à apreciação do Plenário, em 03 de dezembro de 2014, após a exposição do relatório e voto do Ministro-Relator Teori Zavascki e do Ministro Gilmar Mendes, o Ministro Luiz Roberto Barroso pediu vistas.

Retomado o julgamento em 06 de maio de 2015, o recurso sofreu novo pedido de vistas, agora, pela Ministra Rosa Weber.

Somente em 16 de fevereiro de 2017, ou seja, após 02 anos de debates, retomou-se o julgamento, quando, então, foi julgado procedente, e reconhecida a existência de repercussão geral da matéria versada (tema 365: Responsabilidade do Estado por danos morais decorrentes de superlotação carcerária - de 08/06/2011).

Em síntese, como o dano à integridade física e psíquica do detento restou estava comprovada, o debate ficou circunscrito à responsabilidade civil do Estado, de indenizar ou, não, os danos morais sofridos pelos presos, que estão sob custódia do Estado.

\section{FUNDAMENTOS JURÍDICOS DA DECISÃO}

O debate do tema no Supremo Tribunal Federal foi intenso, especialmente quanto à falência do sistema prisional brasileiro, tendo como vencedor, o voto proferido pelo relator Ministro Teori Zavascki.

3 Ibidem, p. 06. 


\section{Personalidade Acadêmica Homenageada:}

Carlos Aurélio Mota de Souza (Universidade Ibirapuera - UNIB)

Destaca o iminente ministro que os fatos são incontroversos e que a situação desumana e degradante dos presídios atenta contra um padrão mínimo de dignidade da pessoa humana, em desconformidade com o previsto no artigo 5, inciso XLIX de que "é assegurado aos presos o respeito à integridade física e moral" e inciso XLVII de que "não haverá penas: e) cruéis".

A questão controvertida, a ser analisada pela Suprema Corte, seria sobre a obrigação, ou não, do Estado indenizar os danos morais sofridos pelos presos.

A responsabilidade do Estado é objetiva, nos termos do art. 37, § 6 da Constituição, que dispõe que "as pessoas jurídicas de direito público e as de direito privado prestadoras de serviços públicos responderão pelos danos que seus agentes, nessa qualidade, causarem a terceiros, assegurado o direito de regresso contra 0 responsável nos casos de dolo e culpa".

Portanto, bastaria provar que o nexo causal do dano moral acometido aos presos decorre da atuação omissiva da Administração Pública, ou dos seus agentes.

Ocorre que, como o dano moral restou incontroverso, e o Estado é responsável pela guarda e segurança dos presos, que se encontram sob sua custódia legal, nada mais acertado do que imputar o dever ao Estado de zelar pelas condições mínimas de dignidade dos presos.

Configurado o nexo causal entre o dano e a ação omissiva do Estado, entendeu o Ministro pelo conhecimento e procedência do recurso.

Quanto a tese fundada no Princípio da Reserva do Possível, suscitada como defesa pelo Estado, de que não possui recursos financeiros suficientes, entendeu o Ministro, que tal Princípio não se aplica diante da inobservância do mínimo existencial, que ocorreu no caso.

Neste sentido, a Ministra Cármen Lúcia, foi ainda mais enfática:

Apenas uma última referência, Presidente, sobre a reserva do possível e o mínimo existencial: é que aqui não se trata do mínimo existencial; nós estamos falando de existência. E a Constituição, no artigo 1, faz referência à dignidade da pessoa humana, e, no artigo 170, refere-se, expressamente, à existência digna, o que vale para todos, e, em especial, para quem está sob a custódia do Estado. ${ }^{4}$

4 Ibidem, p. 188. 


\title{
Personalidade Acadêmica Homenageada: \\ Carlos Aurélio Mota de Souza (Universidade Ibirapuera - UNIB)
}

Ademais, alega que o dano moral do preso não é questão sobre a concretização de direitos constitucionais, em especial, de direitos sociais, que dependem da adoção de políticas públicas para a sua efetivação.

Nesta linha, também é o pensamento do Ministro Celso de Mello:

\begin{abstract}
Há, efetivamente, no Brasil, um claro e indisfarçável "estado de coisas inconstitucional" resultante da omissão do Poder Público em implementar medidas eficazes de ordem estrutural que neutralizem a situação de absurda patologia constitucional gerada, incompreensivelmente, pela inércia do Estado que descumpre a Constituição Federal, que ofende a Lei de Execução Penal e que fere o sentimento de decência dos cidadãos desta República. No exame da grave questão ora submetida ao nosso exame, é preciso não desconsiderar a função contramajoritária que cabe ao Supremo Tribunal Federal exercer no Estado Democrático de Direito e que legitima, precipuamente, a proteção das minorias e dos grupos vulneráveis, sob pena de comprometimento do próprio coeficiente de legitimidade democrática das ações estatais. Cabe ter presente, bem por isso, consideradas as dificuldades que podem derivar da escassez de recursos - com a resultante necessidade de o Poder Público ter de realizar as denominadas "escolhas trágicas" (em virtude das quais alguns direitos, interesses e valores serão priorizados "com sacrifício" de outros) -, o fato de que, embora invocável como parâmetro a ser observado ela decisão judicial, a cláusula da reserva do possível encontrará, sempre, insuperável limitação na exigência constitucional de preservação do mínimo existencial, que representa, no contexto de nosso ordenamento positivo, emanação direta do postulado da essencial dignidade da pessoa humana, tal como tem sido reconhecido pela jurisprudência constitucional desta Suprema Corte. $^{5}$
\end{abstract}

Destarte, foi fixada como tema de repercussão geral, sob o número 365, a seguinte ementa:

Considerando que é dever do Estado, imposto pelo sistema normativo, manter em seus presídios os padrões mínimos de humanidade previstos no ordenamento jurídico, é de sua responsabilidade, nos termos do art. 37, $\$ 6$ da Constituição, a obrigação de ressarcir os danos, inclusive morais, comprovadamente causados aos detentos em decorrência da falta ou insuficiência das condições legais de encarceramento. 6

\footnotetext{
5 lbidem, p. 166.

6 Ididem, p. 02.
} 


\title{
Personalidade Acadêmica Homenageada: \\ Carlos Aurélio Mota de Souza (Universidade Ibirapuera - UNIB)
}

Votaram com o relator os Ministro Gilmar Mendes e Dias Toffoli, e as Ministras Rosa Weber e Cármem Lúcia, os quais concordaram com o pagamento pelo Estado de indenização pecuniária fixa, nos moldes do pedido do Recurso Especial.

Já os Ministros Edson Fachin e Marco Aurélio, muito embora acompanhando o voto do relator, divergiram quanto à indenização, ampliando para o pagamento de um valor mensal enquanto perdurar a situação insalubre ou degradante.

O Ministro Roberto Barroso, entretanto, abriu divergência e foi acompanhado pelos Ministros Luiz Fux e Celso de Mello.

A natureza divergente do voto do Ministro Barroso foi, também, em relação à indenização, partindo da ideia de que há dano e nexo causal.

Entende o Ministro, que o pagamento de um valor pecuniário aos presos é inviável por parte de Estados que já não conseguem manter os presídios em condições humanas e, também, porque tal indenização não faria melhorar a situação dos presos. Assim, argumenta:

\begin{abstract}
Nesse contexto, me parece que a entrega de uma indenização pecuniária confere uma resposta pouco efetiva aos danos morais suportados pelos presos. Afinal, o detento que postular a indenização continuará submetido às mesmas condições desumanas e degradantes após a condenação do Estado. O dinheiro que lhe será entregue terá pouca serventia para minorar as lesões existenciais sofridas. Ao lado disso, a reparação monetária muito provavelmente acarretará a multiplicação de demandas idênticas e de condenações dos Estados. Assim, esta solução, além de não eliminar ou minorar as violações à dignidade humana dos presos, tende a agravá-las e perpetuá-las, já que recursos estatais escassos, que poderiam ser utilizados na melhoria do sistema, estariam sendo drenados para as indenizações individuais. ${ }^{7}$
\end{abstract}

Assim, a solução que propõe o Ministro Roberto Barroso, vista como um verdadeiro ativismo judicial, passa pela ideia de remição da pena, como melhor explica em seu voto:

Nessa linha, a solução que se propõe é a de que os danos morais causados aos presos em função da superlotação e de condições degradantes sejam reparados, preferencialmente, pelo mecanismo da remição de parte do tempo de execução da pena, em analogia ao art. 126 da Lei de Execução

7 Ibidem, p. 45. 


\title{
Personalidade Acadêmica Homenageada: \\ Carlos Aurélio Mota de Souza (Universidade Ibirapuera - UNIB)
}

\begin{abstract}
Penal, que prevê que "[o] condenado que cumpre a pena em regime fechado ou semiaberto poderá remir, por trabalho ou por estudo, parte do tempo de execução da pena". Vale dizer: a cada " $x$ " dias de cumprimento de pena em condições desumanas e degradantes, o detento terá direito à redução de 1 dia de sua pena. Como a "indenização mede-se pela extensão do dano", a variável " $x$ ", isto é, a razão entre dias cumpridos em condições adversas e dias remidos, será fixada pelo juiz, de forma individualizada, de acordo com os danos morais comprovadamente sofridos pelo detento. Proponho, assim, que a contagem do tempo de remição seja feita à razão de 1 dia de pena a cada 3 a 7 dias de encarceramento em condições degradantes, a depender da gravidade dos danos morais sofridos nessas circunstâncias. Eventual dificuldade no arbitramento do quociente de remição da pena em cada caso concreto não será, por evidente, uma peculiaridade deste mecanismo de reparação de danos. Na verdade, a dificuldade está na própria mensuração dos atributos humanos, ou seja, na necessidade de "quantificar o inquantificável" que é inerente ao dano moral e está presente de igual modo (e mesmo de forma mais grave) na reparação pecuniária. Apenas subsidiariamente, caso o detento já tenha cumprido integralmente a pena e não seja possível aplicar-lhe a remição, a indenização das lesões existenciais suportadas pelo detento poderá se dar sob a forma pecuniária. Nessa hipótese, a ação para ressarcimento dos danos morais deverá ser proposta no juízo cível. 8
\end{abstract}

E o Ministro Barroso justifica a sua solução de remir um dia pena a cada 3 a 7 dias de encarceramento em condições degradantes, por se justificar sistematicamente e confere benefícios mútuos às partes, seja ao Estado que utilizaria o valor da indenização para investir na melhora das condições dos presídios, seja para o réu preso, que teria sua saída antecipada. Destaca-se o trecho mencionado pelo ilustre Ministro:

Por fim, é importante ter em conta que a solução proposta se justifica pelo caráter estrutural e sistêmico das graves disfunções do sistema prisional brasileiro. Como se viu, o descumprimento do dever estatal de garantir condições dignas de encarceramento encontra-se diretamente relacionado a uma deficiência crônica de políticas públicas prisionais adequadas, que atinge boa parte da população carcerária. Trata-se de um verdadeiro estado de coisas inconstitucional, cuja superação é complexa e custosa e exige a execução de um amplo conjunto de medidas, articulado por todas as esferas de poder. É diante desse contexto que se afirma que a entrega de uma indenização pecuniária confere uma resposta pouco efetiva aos danos morais suportados pelos presos e que é preciso adotar um modelo de reparação alternativo, que opere de forma não pecuniária, por meio da remição da pena.

8 Ibidem, p. 82. 


\title{
Personalidade Acadêmica Homenageada: \\ Carlos Aurélio Mota de Souza (Universidade Ibirapuera - UNIB)
}

O caro Ministro Edson Fachin, analisando o voto divergente e contrário a ele pelo seu ativismo, questiona: "pode o Poder Judiciário localizar um equivalente funcional não previsto em lei para estabelecer um modo de remição de pena que o legislador ainda não fez?"

Em concordância, e socorro, ao voto divergente, o Ministro Luiz Fux, assinala que existem os poderes instrumentais do juiz:

\begin{abstract}
A Constituição estabelece regras in procedendo para o juiz que vai julgar, que são repisadas pelo novo Código de Processo Civil, regras essas que tem como destinatário o magistrado, para que ela possa proferir uma decisão, o máximo possível, efetiva, eficiente e menos onerosa. (...) Com a devida vênia dos que entendem em contrário, o meu modo é exatamente essa proposta do Ministro Roberto Barroso, que é uma proposta - eu reafirmo - que tem base legal no art. 8 do novo Código de Processo Civil. Ela tem base no princípio da juridicidade - que não abarca só o princípio da legalidade, como tivemos oportunidade, uma vez, de debater - e ela tem sobrejuridicidade, porque a Lei nova prevê esse instituto. E nada mais razoável que, diante desse novo problema, dessa nova questão, o Judiciário se antecipe, até porque nós estamos na Suprema Corte, daqui não há outra Corte para reclamar. ${ }^{9}$
\end{abstract}

Também em sentido contrário ao voto divergente, a Ministra Rosa Weber analisa que a remição da pena tem natureza jurídica diversa e incompatível com a natureza da indenização. Enquanto a remição da pena é um prêmio dado ao réu pelo seu trabalho, estudo e leitura em prol da sua ressocialização, a indenização é a reparação de um dano.

No caso, a indenização não pode ser vista como um prêmio para o preso, mas como um mecanismo de revisão das condutas do Estado:

Em qualquer hipótese, observo que tanto a remição pelo estudo como a
remição pelo trabalho, as duas categorias básicas citadas pelo art. 126 da
Lei de Execuções Penais, pressupõem prática de ato pelo reeducando,
indicativo de seu interesse na ressocialização. Trata-se de um agir orientado
a fim positivamente valorado pela Lei de Execuções Penais. Ainda que o art.
$126, \S 4$ da LEP autorize a remição ao preso impossibilitado, por acidente,
de prosseguir no trabalho ou estudo, o que se tem na base do instituto é a
vontade do interessado, interrompida por motivos alheios ocorridos enquanto
este exercia tal autodeterminação. (...) Já na hipótese ora em exame, os
presos não agem nem se omitem, e sequer entra em conta o que eles

9 Ibidem, p. 158. 


\title{
Personalidade Acadêmica Homenageada: \\ Carlos Aurélio Mota de Souza (Universidade Ibirapuera - UNIB)
}

\begin{abstract}
poderiam fazer ou deixar de fazer, dadas condições reais ou ideais. Esse não é o ponto. Eles sofrem a ação ou omissão. São sujeitos passivos da conduta a ser valorada, positiva ou negativamente, e esta deriva do Estado causador do dano. Evidencia-se assim nítida diferença entre as hipóteses de remição penal, legal ou jurisprudencial, e a hipótese dos autos, pertinente à responsabilidade civil do Estado (...). O violar por menos tempo compensaria o reparar o dano causado, exigido pelo direito civil? A responsabilidade civil exige reparação, e abreviar o sofrimento não é necessariamente o mesmo que reparar o sofrimento. A proposta de abreviação da pena, a despeito do seu brilhantismo, não esgota a complexidade do problema, pois não diz com a dignidade do preso, que é o bem ofendido pelo Estado, e sim com a liberdade. São bens jurídicos diversos e tal conclusão decorre da natureza das coisas, embora também se infira da legislação (art. 38 do Código Penal, art. 3 da LEP e art. 5, XLVII-a e XLIX). ${ }^{10}$
\end{abstract}

\section{DIREITOS FUNDAMENTAIS DOS PRESOS E ATIVISMO JUDICIAL}

\author{
A decisão do RE 580.252 está alinhada com uma "Agenda do Sistema \\ Penitenciário" que vem sendo conduzido pelo Supremo Tribunal Federal, em prol de \\ uma atuação positiva por parte dos Estados - Poder Executivo. \\ Integra o programa, segundo citação da Ministra Rosa Weber, as seguintes \\ ações:
}

(i) RE no 592.581/RS, de relatoria do Ministro Ricardo Lewandowski, no qual o Tribunal assentou, em regime de repercussão geral, que "É lícito ao Judiciário impor à Administração Pública obrigação de fazer, consistente na promoção de medidas ou na execução de obras emergenciais em estabelecimentos prisionais para dar efetividade ao postulado da dignidade da pessoa humana e assegurar aos detentos o respeito à sua integridade física e moral, nos termos do que preceitua o art. 5o, XLIX, da Constituição Federal, não sendo oponível à decisão o argumento da reserva do possível nem o princípio da separação dos poderes". (ii) ADPF no 347/DF, de relatoria do Ministro Marco Aurélio, via da qual o Tribunal declarou, em medida cautelar, o estado de coisas inconstitucional do sistema penitenciário brasileiro, presente o quadro de violação massiva e persistente de direitos humanos dos detentos, decorrente de falhas estruturais e da falência de políticas públicas. A medida cautelar foi ainda deferida para determinar a realização de audiências de custódia, viabilizando o comparecimento do preso perante a autoridade judiciária em até 24 (vinte e quatro) horas contadas do momento da prisão, e o descontingenciamento do Fundo Penitenciário Nacional (Funpen), sem qualquer tipo de limitação, para utilização na finalidade para a qual foi criado, proibindo a realização de novos contingenciamentos. (iii) RE no 841.526/RS, de relatoria do Ministro Luiz Fux,

10 Ibidem, p. 132. 


\title{
Personalidade Acadêmica Homenageada: \\ Carlos Aurélio Mota de Souza (Universidade Ibirapuera - UNIB)
}

\begin{abstract}
julgado pelo Pleno em 30.3.2016 com fixação de tese de repercussão geral (tema 592) no seguinte sentido: "Em caso de inobservância do seu dever específico de proteção previsto no art. 5o, inciso XLIX, da Constituição Federal, o Estado é responsável pela morte de detento". (iv) RE no 641320/RS, de relatoria do Ministro Gilmar Mendes, que discutiu a possibilidade do cumprimento de pena em regime mais benéfico ao sentenciado quando não houver vagas em estabelecimento penitenciário adequado. De acordo com o voto do Relator, havendo falta de vagas no regime semiaberto, 0 juiz deverá providenciá-las mediante a saída antecipada de sentenciados desse regime, que deverão ser colocados em liberdade monitorada eletronicamente (por meio de dispositivos como a tornozeleira eletrônica). O julgamento foi concluído em 11.5.2016, com o que o Pleno fixou a seguinte tese de repercussão geral (tema 423): "a) a falta de estabelecimento penal adequado não autoriza a manutenção do condenado em regime prisional mais gravoso; b) os juízes da execução penal poderão avaliar os estabelecimentos destinados aos regimes semiaberto e aberto, para qualificação como dequados a tais regimes. São aceitáveis estabelecimentos que não se qualifiquem como "colônia agrícola, industrial" (regime semiaberto) ou "casa de albergado ou estabelecimento adequado" (regime aberto) (art. 33, §10, alíneas "b" e "c"); c) havendo déficit de vagas, deverá determinar-se: (i) a saída antecipada de sentenciado no regime comfalta de vagas; (ii) a liberdade eletronicamente monitorada ao sentenciado que sai antecipadamente ou é posto em prisão domiciliar por falta de vagas; (iii) o cumprimento de penas restritivas de direito e/ou estudo ao sentenciado que progride ao regime aberto. Até que sejam estruturadas as medidas alternativas propostas, poderá ser deferida a prisão domiciliar ao sentenciado. ${ }^{11}$
\end{abstract}

Essa "Agenda do Sistema Penitenciário" tem pontos em comum com o recurso ora analisado, pois todos (i) declaram o estado inconstitucional do sistema penitenciário brasileiro, (ii) exigindo uma postura proativa por parte do Executivo e (iii) concedendo benefícios aos detentos quando em situação mais gravosa, ou degradante.

É nítida o ativismo do Judiciário nestes casos, em que tal poder vem paulatinamente fazendo exigências, de toda sorte, para a solução do precário sistema prisional brasileiro.

A noção contemporânea do Princípio da Separação dos Poderes é substancialmente diferente do contexto do nascimento do Estado Liberal-Burguês, em que se pretendia limitar o poder do Executivo.

${ }^{11}$ Ibidem, p. 128. 


\section{Personalidade Acadêmica Homenageada:}

Carlos Aurélio Mota de Souza (Universidade Ibirapuera - UNIB)

Atualmente, conforme ensina Nuno PIÇARRA, "o sistema de freios e contrapesos determinou, afinal, não um equilíbrio permanente entre os poderes separados, mas sim uma predominância cíclica de cada um deles". ${ }^{12}$

Assim, no Estado Moderno, o papel do Legislativo teve maior destaque, pois como o poder é do povo e a única forma de manifestação do poder soberano é através da produção legislativa. Inclusive, todas as funções do Estado são meramente jurídicas e sua classificação precisa ser feita a partir da legislação.

Ocorre que, com a pós-modernidade ou modernidade tardia, o primado não é mais da liberdade ou da igualdade, mas da governabilidade..$^{13}$

$\mathrm{Na}$ democracia, em que o governo é da maioria, para se alcançá-la, a democracia precisa superar conflitos de interesses de vários grupos sociais. Ocorre que, o Legislativo em muitos momentos não é capaz de produzir consenso. E, de fato, o Legislativo não é capaz de produzir consenso, seja porque não consegue formar a maioria, ou seja, simplesmente, por que não quer, em razão do peso político da decisão.

No caso, atuar em favor do sistema prisional não trás voto, seja para os membros do Executivo quanto para o Legislativo.

Destarte, neste momento de vácuo, o Poder Judiciário se torna legitimado a atuar. Ainda mais, quando se trata da violação de direitos fundamentais tão caros, como a dignidade da pessoa humana, integridade física e moral. Corroborando, assinala BARROSO:

O Poder Judiciário é obrigado a intervir para garantir a efetividade das normas constitucionais, o que reforça a tênue fronteira entre o político e o jurídico na contemporaneidade. Cumpre ressaltar que a interferência do Judiciário, nesses assuntos, deve se dar de maneira subsidiária, autocontida e reverente aos outros poderes. ${ }^{14}$

12 PIÇARRA, Nuno apud CARLOS, Fabiano Gonçalves. Separação dos Poderes: da concepção clássica à noção contemporânea. Disponível em:

http://www.ajuris.org.br/OJS2/index.php/REVAJURIS/article/viewFile/428/Ajuris 140 DT Acesso em: 21.02.2018. p. 160.

${ }^{13}$ BARROSO, Luís Roberto. Judicialização, Ativismo Judicial e Legitimidade Democrática. Revista Atualidades Jurídicas - Revista Eletrônica do Conselho Federal da OAB. 4. ed. Jan/Fev 2009. Disponível em: http://www.plataformademocratica.org/Publicacoes/12685 Cached.pdf. Acesso em: 16.02.2018. p. 13.

14 Ibidem, p. 14. 


\title{
Personalidade Acadêmica Homenageada:
}

Carlos Aurélio Mota de Souza (Universidade Ibirapuera - UNIB)

Destarte, resta claro que o Poder Judiciário, dependendo da afronta constitucional e da necessidade de um atuar contra-majoritário, assume certo protagonismo perante os demais Poderes.

Ademais, é protagonista porque a sociedade demanda cada dia mais contra o Estado, em busca de Direitos e respeito aos direitos fundamentais. Neste sentido, ensina DALLARI:

\begin{abstract}
A separação de poderes foi concebida num momento histórico em que se pretendia limitar o poder do Estado e reduzir o mínimo sua atuação. Mas a evolução da sociedade criou exigências novas, que atingiram profundamente o Estado. Este passou a ser cada vez mais solicitado a agir, ampliando sua esfera de ação e intensificando sua participação nas áreas tradicionais. ${ }^{15}$
\end{abstract}

Diante deste quadro de destaque do Poder Judiciário, nasce o chamado o ativismo judicial, como soluções encontradas para a manutenção e promoção da democracia.

O Ativismo Jurídico iniciou com o modelo de controle de constitucionalidade adotado no Brasil, em que todo juiz, por meio do controle difuso, ou tribunal, por meio do controle concentrado, pode declarar a inconstitucionalidade de uma lei ou ato normativo. Isto conferiu maior responsabilidade ao Supremo Tribunal Federal, apesar de suas decisões serem, para além de jurídicas, políticas.

O instituto pode ser conceituado como a atuação do judiciário para solver conflitos normativos, em contraposição a conflitos de interesses, pois o que importa num Estado de Direito consiste em saber se o legislador, o governo ou o juiz podem praticar determinado ato e se este ato é legítimo.

O Ativismo Judicial, buscou uma releitura moral do Direito, considerando a importância da interpretação e aplicação do ordenamento jurídico, bem como a supervalorização dos princípios em face das regras, principalmente o da dignidade da pessoa.

${ }^{15}$ DALLARI, Dalmo de Abreu. Elementos de teoria geral do Estado. 23 ed. São Paulo: Saraiva, 2002. p. 220. 


\section{Personalidade Acadêmica Homenageada:}

Carlos Aurélio Mota de Souza (Universidade Ibirapuera - UNIB)

Para o Ministro Luís Roberto BARROSO, a ideia de ativismo judicial está associada a "uma participação mais ampla e intensa do Judiciário na concretização dos valores e fins constitucionais, com maior interferência no espaço de atuação dos outros dois Poderes". ${ }^{16}$ Ensina ainda que o ativismo judicial é "uma atitude, a escolha de modo específico e proativo de interpretar a Constituição, expandindo seu sentido e alcance". ${ }^{17}$

Nesta linha é o voto divergente do Ministro, buscando uma nova leitura constitucional e legal para uma mais eficiente resposta ao dano moral sofrido pelos detentos em situação degradante.

Ele sugere a aplicação, por analogia, o mecanismo da remição de parte do tempo de execução da pena, previsto no artigo 126 da Lei de Execução Penal, que prevê que "[0] condenado que cumpre a pena em regime fechado ou semiaberto poderá remir, por trabalho ou por estudo, parte do tempo de execução da pena".

Ou seja, a um certo número de dias de cumprimento de pena em condições desumanas e degradantes, o detento terá direito à redução de 1 dia de sua pena e o juiz fixaria, de forma individualizada, de acordo com os danos morais efetivamente sofridos pelo detento. Assim, o Ministro propõe a razão de 1 dia de pena a cada 3 a 7 dias de encarceramento, a depender do dano sofrido.

Apenas no caso do detento já ter cumprido a pena é que seria fixada uma indenização pecuniária.

Seguindo estas ideias, o ativismo judicial demonstra ser uma medida de concretização da justiça, tanto que recentemente, o Supremo Tribunal Federal decidiu sobre outras questões também importantes, como a união homoafetiva, a interrupção terapêutica da gestação de fetos anencefálicos, as cotas raciais, pesquisas de células tronco, nepotismo, entre outros exemplos.

${ }^{16}$ BARROSO, Luís Roberto. Neoconstitucionalismo e Constitucionalização do Direito. Revista Eletrônica sobre a Reforma do Estado (RERE). Salvador: Instituto Brasileiro de Direito Público, № 9, 2007. Disponível em: http://www.direitodoestado.com.br/rere.asp. Acesso em: 16.02.2018.

17 Idem. 


\title{
Personalidade Acadêmica Homenageada: \\ Carlos Aurélio Mota de Souza (Universidade Ibirapuera - UNIB)
}

O ativismo judicial não se trata de uma interpretação completamente livre do magistrado ao julgar o caso concreto, fazendo uso de fontes desconhecidas ou ainda, com o propósito de afirmar uma posição nitidamente pessoal.

Antes, trata-se de uma postura não ortodoxa de aplicação do direito positivo, com base, principalmente, na força normativa dos princípios constitucionais ou na lógica do sistema constitucional.

Mauro CAPPELLETTI, em “Juízes Legisladores?", ressaltou a mudança do papel do juiz decorrente do abandono da concepção liberal da lei:

\begin{abstract}
É manifesto o caráter acentuadamente criativo da atividade judiciária de interpretação e de atuação da legislação e dos direitos sociais. Deve reiterarse, é certo, que a diferença em relação ao papel mais tradicional dos juízes é apenas de grau e não de conteúdo: mais uma vez impõe-se repetir que, em alguma medida, toda interpretação é criativa, e que sempre se mostra inevitável um mínimo de discricionariedade na atividade jurisdicional. Mas, obviamente, nessas novas áreas abertas à atividade dos juízes haverá, em regra, espaço para mais elevado grau de discricionariedade e, assim, de criatividade, pela simples razão de que quanto mais vaga a lei e mais imprecisos os elementos do direito, mais amplo se torna também o espaço deixado à discricionariedade das decisões judiciais. Esta é, portanto, a poderosa causa da acentuação, que em nossa época, teve o ativismo, o dinamismo e, enfim a criatividade. ${ }^{18}$
\end{abstract}

A cultura jurídica teria passado de um suposto positivismo formalista à maior permeabilidade aos aspectos valorativos das situações, à inovação nos métodos de trabalho e à estimativa dos impactos das decisões judiciais.

\section{CONCLUSÃO}

Estudando a tese de tripartição dos Poderes, incontestável a conclusão de que é saudável a interferência, a interpenetração, entre os Poderes.

Com a propositura da divisão dos poderes do Estado: Legislativo, Executivo e Judiciário, definiu-se que o poder Legislativo tem a função típica de legislar e

18 CAPPELLETTI, Mauro. Juízes Legisladores? Tradução: Carlos Alberto Álvaro de Oliveira. Porto Alegre: S.A. Fabris, 1999. p. 05. 
Personalidade Acadêmica Homenageada:

Carlos Aurélio Mota de Souza (Universidade Ibirapuera - UNIB)

fiscalizar; o Executivo, administrar a coisa pública; já o Judiciário, julgar, aplicando a lei a um caso concreto que lhe é posto, resultante de um conflito de interesses.

Aplicar o sistema de freios e contrapesos significa conter os abusos dos outros poderes para manter certo equilíbrio. Por exemplo, o judiciário, ao declarar inconstitucionalidade de uma Lei é um freio ao ato Legislativo que poderia conter uma arbitrariedade, ao ponto que o contrapeso é que todos os poderes possuem funções distintas, fazendo assim com que não haja uma hierarquia entre eles, tornando-os poderes harmônicos e independentes.

Essa divisão clássica se dá até hoje na maioria dos Estados e está consolidada na Constituição, sendo nela divididas e especificadas as funções de cada poder.

O sistema de freios e contrapesos é fundamental ferramenta de controle e fiscalização dos atos públicos, evitando inconstitucionalidades, ilegalidades e arbitrariedades, como a apronta à integridade física e psíquica dos presos, encarcerados em condições indignas de vida.

A pertinência dos ideais propagados pelos movimentos ativistas, como liderado pelo Ministro Roberto Barroso, são claramente justos e válidos, ainda mais quando declarado o estado inconstitucional do sistema prisional brasileiro, que precisa de soluções criativas dentro do sistema jurídico nacional.

\section{REFERÊNCIAS}

BARROSO, Luís Roberto. Judicialização, Ativismo Judicial e Legitimidade Democrática. Revista Atualidades Jurídicas - Revista Eletrônica do Conselho Federal da OAB. Jan/Fev 2009. Disponível em: http://www.plataformademocratica.org/Publicacoes/12685 Cached.pdf. Acesso em: 16.02.2018. p. 13.

Neoconstitucionalismo e Constitucionalização do Direito. Revista Eletrônica sobre a Reforma do Estado (RERE). Salvador: Instituto Brasileiro de Direito Público, oo 9, 2007. Disponível em: http://www.direitodoestado.com.br/rere.asp. Acesso em: 16.02.2018. 
Personalidade Acadêmica Homenageada:

Carlos Aurélio Mota de Souza (Universidade Ibirapuera - UNIB)

CAPPELLETTI, Mauro. Juízes Legisladores? Tradução: Carlos Alberto Álvaro de Oliveira. Porto Alegre: S.A. Fabris, 1999. p. 05.

DALLARI, Dalmo de Abreu. Elementos de teoria geral do Estado. 23 ed. São Paulo: Saraiva, 2002. p. 220.

PIÇARRA, Nuno apud CARLOS, Fabiano Gonçalves. Separação dos Poderes: da concepção clássica à noção contemporânea. Disponível em: http://www.ajuris.org.br/OJS2/index.php/REVAJURIS/article/viewFile/428/Ajuris 140 DT Acesso em: 21.02.2018. 